\title{
A List of Plants from Ning-po, Cheh-kiang.
}

(Continued from vol. XXVII. p. 276.)

By

S. Matsuda.

\section{Amarantaceae.}

170. Alternanthera nodiflora R. Br.; Moq. in DC. Prodr. XIII. 2, p. 356 ; Hook. f. Fl. Brit. Ind. IV. 732 ; Forb. et Hemsl. in Journ. Linn. Soc. XXVI. 322.

Nom. Jap. Tsuru-nogeitō.

171. Amarantus paniculata L., Moq. in DC. Prodr. XIII. 2, p. 257 ; Hook. f. Fl. Brit. Ind. IV. 718 ; Forb. et Hemsl. in Journ. Linn. Soc. XXVI. 320 ; Diels in Engl. Bot. Jahrb. XXIX. 316. (Chang, no. $116 a, 116 b$ ).

\section{Chenopodiaceæ.}

172. ? Chenopodium album L.; Moq. in DC. Prodr. XIII. 2, p. 70 ; Benth. Fl. Hongk. 282 ; Forb. et Hemsl. in Journ. Linn. Soc. XXVI. 323 ; Diels in Engl. Bot. Jahrb. XXIX. 315. (Chang, no. 117).

Specimen not very perfect.

173. Ch. ambrosioides L.; Moq, in DC. Prodr. XIII. 2, p. 72 ; Hook. f. Fl. Brit. Ind. V. 4 ; Wight Ic. Pl. Ind. Or. t. 1786 ; Forb. et Hemsl. in Journ. Linn. Soc. XXVI. 324.

Nom. Jap. Aritasô.

\section{Polygonaceæ.}

174. Polygonum alatum Hamilt.; Hook. f. Fl. Brit. Ind. V. 41 ; Forb. et Hemsl. in Journ. Linn. Soc. XXVI. 332 ; Diels in Engl. Bot. Jahrb. XXIX. 313. 
Nom. Jap. Tani-soba.

175. P. hastato-sagittatum Makino in Bot. Mag. Tokyo XVII. 64; Nakai ibidem XXIII. 421 (in Japanese).

Nom. Jap. Nagaba-no-yanonegusa.

This specific name is new to the Chinese flora, but it is most probable that the species is recorded from China under some other name.

176. P. japonicum Meisn. in DC. Prodr. XIX. 112 et 695 ; Fr. Pl. David. 254 ; Forb. et Hemsl. in Journ. Linn. Soc. XXVI. 341 ; Diels in Eng1. Bot. Jahrb. XXIX. 312.

Nom. Jap. Sakura-tade.

177. P. nipponense Makino in Bot. Mag. Tokyo XXIII. 89 ; Nakai ibidem 89 (in Japanese) $;=P$. hastato-sagittatum Makino, $\beta$. latifolium Makino ibidem XVII. $123 ;=P$. strigosum R. Br. var. latifolium Makino in sched., Herb. Imp. Univ. Tokyo. (Chang, no. 118).

Nom. Jap. Yanone-gusa.

This specific name is also new to the Chinese flora, but it is most probable that the species is recorded from China under some other name.

178. P. Posumbu Hamilt. var. Blumei (Meisn.) Herder ; Nakai in Bot. Mag. Tokyo XXIII. (1909) 394 (in Japanese). (Chang, no. 119).

Nom. Jap. Inu-tade.

179. P. Thunbergii Sieb. et Zucc.; Meisn. in DC. Prodr. XIV. 132 ; Fr. et Sav. Enum. Pl. Jap. II. 475 ; Diels in Engl. Bot. Jahrb. XXIX. 314.

Nom. Jap. Mizo-soba.

180. Rumex acetosa I., Meisn. in DC., Prodr. XIV. 64; Bak. et Moore in Journ. Linn. Soc. XVII. 385 ; Forl. et Hemsl. in Journ. Linn. Soc. XXVI. 355 ; Diels in Engl. Bot. Jahrb. XXIX. 311. (Chang, no. $118 a, 118 b$ ).

Nom. Jap. Sukampo.

\section{Lauraceæ.}

181. ? Lindera? Rosthornii Diels in Engl. Bot. Jahrb. XXIX. 350. 
Sterile specimens, determination unsatisfactory. The species is allied as Diels states to L. fragrans Oliv. in Hook. Ic. P1. t. 1788. The latter botanist places this species in the present genus with interrogation.

182. ? Machilus longifolia Bl. in Mus. Bot. Lugd. Bat. I. 331 ; Meisn. in DC. Prodr. XV. 1, p. 43 ; Fr. et Sav. Enum. Pl. Jap. I. 412 ; Engl. Bot. Jahrb. VI. 57 ; Forb. et Hems1. in Journ. Linn. Soc. XXVI. 375. (Chang, no. 120).

Imperfect specimen with $\mathrm{fl}$. buds(?) turned to galls. The back of perula is silky.

\section{Euphorbiaceæ.}

183. Aleurites Fordii Hemsl., Hook. Ic. t. 2802. (Chang, no. 123).

184. Mallotus Apelta Muell. Arg. in Linnæa XXXIV. 189, et in DC. Prodr. XV. 2, p. 963 ; Forb. et Hemsl. in Journ. Linn. Soc. XXVI. 439 ; Diels in Engl. Bot. Jahrb. XXIX. 428; =Rottlera chinensis Juss. ; Benth. Fl. Hongk. 306. (Chang, no. $121 \mathrm{a})$.

185. M. japonicus Muell. Arg. in Linnæa XXXIV. 189, et in DC. Prodr. XV. 2, p. 966 ; Max. in Engl. Bot. Jahrb. VI. 59 ; Forb. et Hemsl. in Journ. Linn. Soc. XXVI. 440 ; Pax in Engl. Bot. Jahrb. XXIX. 428. (Chang, no. 121).

Nom. Jap. Akame-gashiwa.

186. Sapium sebiferum Roxb. Fl. Ind., III. 693 ; Hook. f. Fl. Brit. Ind. V. 470 ; Forb. et Hemsl. in Journ. Linn. Soc. XXVI. 445 ; Diels in Engl. Bot. Jahrb. XXIX. 430. (Chang, no. 122.)

Nom. Jap. Nankin-haze.

\section{Urticaceæ.}

187. Boehmeria grandifolia Wedd.; Forb. et Hemsl. in Journ. Linn. Soc. XXVI. $485 ;=B$. platyphylla Don var. macrophylla Wedd. in DC. Prodr. XVI. 1, p. 213, excl. syn. $B$. longispica Steud.; B. longispica Fr. et Sav., Enum. Pl. Jap. I. 440 ex parte, non Steud. (Chang, no. 130). 
Nom. Jap. Yabu-ma-o.

$B$. holosericea Bl. is not recorded from China; it is a var. of $B$. platyphylla Don (DC. Prodr. 1. c.) after Weddell. Several specimens of Japanese plants named $B$. holosericea B1. seem to be a form of $B$. grandifolia Wedd. $B$. japonica Miq. is often applied to "Yabu-ma-o," but is not adopted in Meikan, or Index P1. Jap. by Prof. Matsumura.

188. B. nivea Gaud.; Benth. Fl. Hongk. 331 ; DC. Prodr. XVI. 1, p. 206 ; Hook. f. Fl. Brit. Ind. V. 985 : Forb. et Hemsl. in Journ. Linn. Soc. XXVI. 486 ; Diels in Engl. Bot. Jahrb. XXIX. 304. (Chang, no. 129).

Nom. Jap. Ma-o.

This is said to be a plant known as China grass or Ramie, of which Chinese grass-cloth is made.

189. B. platyphylla Don, var. stricta C. H. Wright in Journ. Linn. Soc. XXVI. 487 ; Diels in Engl. Bot. Jahrb. XXIX. 304. (Chang, no. 127 a, 127 b).

Hupeh specimen no. 4622 from Henry named B. platyphylla Don ssems to be of var. stricta.

190. B. sp. (Chang, no. 125).

The specimen is indeterminable, fruit being immature. It is somewhat allied to $B$. Zollingeriana Wedd.

191. Broussonetia papyrifera Vent.; Bureau in DC. Prodr. XVII. 224 ; Fr. Pl. David. 269 ; Hook. f. Fl. Brit. Ind. V. 490 ; Bot. Mag. t. 2358 ; Forb. et Hemsl. in Journ. Linn. Soc. XXVI. 455 ; Diels in Engl. Bot. Jahrb. XXIX. 298. (Chang, no. 125).

Nom. Jap. Kajinoki.

192. Celtis sinensis Pers.; Benth. Fl. Hongk. 324; Planch. in DC. Prodr. XVII. 172; Forb. et Hemsl. in Journ. Linn. Soc. XXVI. 450 ; Diels in Engl. Bot. Jahrb. XXIX. 297.

Nom. Jap. Enoki.

193. Ficus formosana Max. in Mél. Biol. XI. 331; King in Ann. Bot. Gard. Calc. I. p. 153, t. 177 A ; Forb. et Hemsl. in Journ. Linn. Soc. XXVI. 459 ; Diels in Engl. Bot. Jahrb. XXIX. 300. (Chang, no. 124).

F. taiwaniana Hayata, Materials for F1. Formos. 277, is distinguished from $F$. formosana by having pyriform receptacle, 
while it is subglobose in the latter species.

194. F. pumila L.; Forb. et Horb. in Journ. Linn. Soc. XXVI. 465; Diels in Engl. Bot. Jahrb. XXIX. 299 ; Makino in Bot. Mag. Tokyo XVIII. 152 et XX. 43.

Nom. Jap. Ōitabi.

195. Morus alba L.; Bureau in DC. Prodr. XVII. 238 ; Hook. f. Fl. Brit. Ind. 492; Forb. et Hemsl. in Journ. Linn. Soc. XXVI. 455. (Chang, no. 128.)

Nom. Jap. Kuwa (桑).

196. Nanocnide japonica Bl. Mus. Bot. Lugd.-Bat. II. 155; t. 17 ; DC. Prodr. XVI, 1, 69 ; Max. in Mél. Biol. IX. 627 ; Forb. et Hemsl. in Journ. Linn. Soc. XXVI. 473 ; Diels in Engl. Bot. Jahrb. XXIX. 301 ;

\section{forma?}

The present specimen differs from the type in the larger stature :

Leaves are about $4 \mathrm{~cm}$. long and as much broad, about 9toothed on each side, the peduncle of the male fl. attaining about $7 \mathrm{~cm}$; segments of male fl. are transversely crested a little below the apex.

197. Pellionia scabra Benth. F1. Hongk. 330 ; Wedd. in DC. Prodr. XVI. 1, p. 166 ; Max. in Mél. Biol. IX. 633; Forb. et Hemsl. in Journ. Linn. Soc. XXVI. 481; Matsum. et Hayata, Enum. P1. Formos. 383. (Chang, no. 131).

\section{Juglandaceæ.}

198. Pterocarya Paliurus Batalin in Act. Hort. Petrop. XIII. 101 ; Fr. in Journ. de Bot. (1898) 318; Diels in Engl. Bot. Jahrb. XXIX. 274. (Chang, no. 132).

199. P. stenoptera DC. Prodr. XVI. 2, p. 140 ; Max. in Mél. Biol. VIII. 639 ; Forb. et Hemsl. in Journ. Linn. Soc. XXVI. 494; Diels in Engl. Bot. Jahrb. XXIX. 277.

\section{Cupuliferæ.}

200. Quercus glauca Thunb.; DC. Prodr. XVI. 2, p. 100; Hance in Journ. Bot. (1875) 363 ; Hook. f. Fl. Brit. Ind. V. 
604; Banks, Icon. Select. Kæmpf. t. 17 ; Forb. et Hemsl. in Journ. Linn. Soc. XXVI. 515; Diels in Engl. Bot. Jahrb. XXIX. 293.

Nom. Jap. Arakashi.

201. Passania glabra Oerst., Makino in Bot. Mag. Tokyo (1900) 166, $186 ;=$ Quercus Thalassica Hance; Benth. F1. Hongk. 321 ; DC. Prodr. XVI. 2, p. 84; Fr. et Sav. Enum. P1. Jap. I., 447 ; Forb. et Hemsl. in Journ. Linn. Soc. XXVI. 521 ; Diels in Engl. Bot. Jahrb. XXIX. 294. (Chang, no. 134.)

Nom. Jap. Shirifuka.

\section{Salicaceæ.}

202. Salix sp. (Chang, no. 133. $\uparrow$ )

Scale ovate, stamens 2, anterior gland fleshy, reddish, posterior often irregularly divided.

\section{Ceratophyllaceæ.}

203. Ceratophyllum demersum L.; DC. Prodr. III. 73 ; Hook. f. Fl. Brit. Ind. V. 639 ; Forb. et Hemsl. in Journ. Linn. Soc. XXVI. 538 ; Diels in Engl. Bot. Jahrb. XXIX. 321.

Nom. Jap. Kingyo-mo.

The fruit smooth, with 2 long spines near base.

\section{Coniferae.}

204. Juniperus chinensis L.; Parl. in DC. Prodr. XVI. 2, p. 487 ; Sieb. et Zucc. F1. Jap. tt. 126, 127 ; Franch. Pl. David. I. 291 ; Forb. et Hems1. in Journ. Linn. Soc. XXVI. 541. (Chang, no. 135.)

Nom. Jap. Ibuki.

205. J. sp.; Hayata in Journ. Linn. Soc. XXXIX. 89.

\section{Hydrocharitaceæ.}

206. Hydrilla verticillata Royle; Casp. in Pringsh. Jahrb. I. 494; Hook. f. Fl. Brit. Ind. v. 659 ; Forb. et Hemsl. in 
Journ. Linn. Soc. XXVI. 1; Diels in Engl. Bot. Jahrb. XXIX. 220.

Nom. Jap. Kuromo.

\section{Orchiduceæ.}

207. Goodyera Schlechtendaliana Reichb. f. in Linnæa XXII. 861 ; Fr. et Sav. Enum. Pl. Jap. II. ; Rolfe in Journ. Linn. Soc. XXXVI. 46 ; Kränzlin in Engl. Bot. Jahrb. XXIX. 269 ;=G. secundiflora Griff. ; Hook. f. F1. Brit. Ind. VI. 113.

Nom. Jap. Miyama-udzura.

Distinguished from $G$. repens $\mathrm{R}$. Br. by having fl. mottled in most cases, and bracts shorter than the flowers.

208. Spiranthes australis Lindl. ; Hook. f. Fl. Brit. Ind. VI. 102 ; Forb. et Hemsl. in Journ. Linn. Soc. XXXVI. 41 ; Diels in Engl. Bot. Jahrb. XXIX. 269. (Chang, no. 136.)

\section{Scitamineæ.}

209. ?Musa Basjoo Sieb. ; Bak. in Bot. Mag. t. 7182 ; Wright in Journ. Linn. Soc. XXXVI. 74. (Chang, no. 137.)

Nom. Jap. Bashô (芭蕉).

210. Canna sp. (Chang, no. 138.)

The specimen has fl. yellow, brown spotted or blotched.

\section{Haemodoraceæ.}

211. Aletris japonica Lamb.; S. Moore in Journ. Bot. XVI (1878)138; Wright in Journ. Linn. Soc. XXXVI. 76. (Chang, no. 139.)

Nom. Jap. Sokushin-ran.

212. Liriope spicata Lour.; Wright in Journ. Linn. Soc. XXXVI. 79 ;=Ophiopogon spicatus Gawl. ; Diels in Engl. Bot. Jahrb. XXIX. 253.

\section{Iridaceæ.}

213. Iris tectorum Max. in Mél. Biol. VII. 563 ; Gartenflora t. 716 ; Bot. Mag. t. 6118 ; Bak. Handb. 23 ; Wright in Journ. 
Linn. Soc. XXVI. 85 ; Diels in Engl. Bot. Jahrb. XXIX. 262. (Chang, no. 140.)

Nom. Jap. Ichihatsu.

\section{Dioscoreaceæ.}

214. Dioscorea Batatus Decne.; Benth. F1. Hongk. 368 ; Makino, Phanerog. Jap. Ic. Ill. tt. 93-95; Wright in Journ. Linn. Soc. XXXVI. 91. (Chang, no. 141,)

Nom. Jap. Naga-imo.

The specimen is of a form with subtrilobed leaves.

215. D. Tokoro Makino in Bot. Mag. Tokyo (1889)112, et Phanerog. et Pterid. Jap. Ic. Ill. III. t. 79. (Chang, no. 141.)

Nom. Jap. Oni-tokoro.

\section{Liliaceæ.}

216. Asparagus lucidus Lindl.; Benth. Fl. Hongk. 371 ; Miq. in Ann. Mus. Bot. Lugd.-Bat. III. 151; Kunth, Enum. Pl. v. 72 ; Bak. in Journ. Linn. Soc. XIV. 605 ; Wright in Journ. Linn. Soc. XXXVI. 102 ; Diels in Engl. Bot. Jahrb. XXIX. 246. (Chang, no. 144.)

Nom. Jap. Kusa-sugikadzura.

Distinguished from $A$. schoberioides Kunth, thus :

Pedicel articulate below the fl......A. schoberioides.

\section{in the middle......A. Iucidus.}

217. Hemerocallis fulva L.; Bot. Mag. t. 64; Kunth, Enum. Pl. IV. 588 ; Fr. et Sav. Enum. Pl. Jap. II. 80 ; Bak. in Journ. Linn. Soc. Bot. XI. (1870); Hook. f. Fl. Brit. Ind. VI. 326 ; Wright in Journ. Linn. Soc. XXXVI. 115. (Chang, no. 142.)

218. Lilium Brownii F. E. Brown; Wright in Journ. Linn. Soc. XXXVI. 128 ; Diels in Engl. Bot. Jahrb. XXIX. 243 ;

? var. viridulum Baker in Gard. Chron. (1885.) pt. II. p. 134, et (1891) pt. II. p. 225. (Chang, no. 145.)

The upper leaves (the lower ones being absent) of the present specimen are oblong-lanceolate, subacuminate, sub-5nerved; corolla seems to be white, though the color is not 
distinct in dried state.

L. Brownii has several varieties, of which some have white fl., and others have broader leaves. The present specimen is allied to L. japonicum, but differs from it in short broad leaves; also it is allied to $L$. nepalense C. Don, but differs from it in the white color of fl., which is yellow in the type of the Nepal plant.

219. ? Lilium cordifolium Thunb. ; Sieb. et Zucc. Fl. Jap. I. (1835) p. 33, tab. 13. II, et 14; Kunth, Enum. P1. IV. (1843) 268 ; Wright in Journ. Linn. Soc. XXXVI. 130.

Very imperfect specimen consisting of a single flower. Mr. Makino changed the name of the present sp. to Cardiocrinum cordatum. (Confr. Bot. Mag. Tokyo (1913) p. 124.)

\section{Paris sp.}

Leaves 9 -verticillate, petiolate, petiole $1 \mathrm{~cm}$. long, lamina $(9 \times 2 \mathrm{~cm}$.) oblong lanceolate, subacuminate, peduncle about $1.3 \mathrm{dm}$., fl. solitary, sepals 8 , like the lamina in form and texture, but much smaller $(4 \times 1 \mathrm{~cm}$.), petals 6 (?), linear, 1.2 $\mathrm{cm}$. long ; stamens 14 (?), anthers $6 \mathrm{~mm}$. long, filament half as long.

Many species of the genus are recorded from China; the descriptions of most of them do not agree with the present specimen, which is not very perfect.

\section{Polygonatum officinale All.}

? var. Maximowiczii Fr. Schm.; Max. in Mél. Biol. XI. 847 ; Wright in Journ. Linn. Soc. XXXVI. 108. (Chang, no. 143).

The present specimen has the leaves scabrous beneath, filament pubsscent, especially towards the base, twice as long as the anther. Stature seems to be smaller than the Japanese specimens of this variety. The type of $P$. officinale has leaves glabrous beneath, filament glabrous, subequel to the anthers in length.

222. Smilax herbacea L. var. nipponica Max.; A. DC. Monogr. Phan. I. 52 ; Wright in Journ. Linn. Soc. XXXVI. 98. (Chang, no. 146 a, 146 b.)

Nom. Jap. Shiode. 
223. Tricyrtis macropoda Miq.; Gartenflora t. 613 ; Fr. et Sav. Enum. Pl. Jap. II. 74 ; Bak. in Journ. Linn. Soc. XVII. 464 ; Hemsl. in Journ. Bot. XIV. 210 ; Wright in Journ. Linn. Soc. XXXVI. 142 ; Diels in Engl. Bot. Jahrb. XXIX. 241.

\section{Commelinaceæ.}

224. ? Aneilema Keisak Hassk. ; C. B. Clarke in DC. Monogr. Phan. III, 209 ; Diels in Engl. Bot. Jahrb. XXIX. 237 ; Wright in Journ. Linn, Soc. XXXVI. 152. (Chang, no. 147).

Fl. seem to be much larger than those of common Japanese specimens.

\section{Palmæ.}

225. ? Trachycarpus excelsus Wendl.; Wright in Journ. Linn. Soc. XXXVI. 168. (Chang, no. 148).

Imperfect specimen.

\section{Araceæ.}

226. Acorus gramineus Ait. Hort. Kew. I. 474; Engl. in DC. Monogr. Phan. II. 218; Hook. f. Fl. Brit. Ind. VI. 556 ; Diels in Engl. Bot. Jahrb. XXIX. 234; Brown in Journ. Linn. Soc. XXXVI. 187.

Nom. Jap. Seki-shö.

227. Arisaema heterophyllcim B1. ; Kunth, Enum. P1. III. 20 ; Makino in Bot. Mag. Tokyo XV. 134; Brown in Journ. Linn. Soc. XXXVI. $178 ;=A$. Thunbergii Bl. var. heterophyllum Engl. in DC. Monogr. Phan. II. 546 ; Diels in Engl. Bot. Jahrb. XXIX. $236 ;=A$. Thunbergii Savat. in Iinuma, Somoku-Zusetsu, ed. 2., XIX. t. 14, non Bl. (Chang, no. 150 )

Nom. Jap. Maizuru-tennanshō.

228. Pinellia tuberifera Tenore; Engl. in DC. Monogr. Phan. II. 566 ; Palibin in Acta Hort. Petrop. XIX. (1901); 17; Engl. in Engl. Bot. Jahrb. XXIX. 236 ; Brown in Journ. Linn. Soc. XXXVI. 174. (Chang, no. 149.)

Nom. Jap. Karasu-bishaku. 


\section{Alismaceæ.}

229. Alisma Plantago L.; Micheli in DC. Monogr. Phan. III. 32 ;

var. angustifolium Kunth, Enum. P1. III. 148; Wright in Journ. Linn. Soc. XXXVI. 188. (Chang, no. 151.)

Nom. Jap. Hera-omodaka.

\section{Cyperaceæ.}

230. Carex brunnea Thunb.; Clarke in Journ. Linn. Soc. XXXVI. 278 ; Diels in Engl. Bot. Jahrb. XXIX. 330 ; Kük. in Engl. Pflreich. Heft. 38 (Cyperaceæ-Caricoideæ) 599. (Chang, no. 154).

Nom. Jap. Nagiri-suge.

231. C. dispalatha Boott, Carex I. 205; Fr. et Sav. Enum. P1. Jap. II. pp. 151, 580 ; Clarke 1. c. $283 . \quad$ (Chang, no. 155.)

Nom. Jap. Kasa-suge.

232. ? C. japonica Thunb., var. chlorostachys Kük. 1. c. 620.

Specimens imperfect with undeveloped flowers.

233. ? C. Morrowii Boott ; Miq. Prol. 79 ; Boeck. in Linnæa XL. 450.

This sp. is not cited by Clarke in Journ. Linn. Soc. XXXVI. The specimen wants leaves, determination doubtful.

234. Eleocharis acicularis R. Br.; Kunth, Enum. Pl. II. 141 ; Clarke in Hook. f. Fl. Brit. Ind. VI. 628, et in Journ. Linn Soc. XXXVI. 225. (Chang, no. 156.)

Nom. Jap. Matsuba-i.

235. ? E. tetraquetra Nees; Clarke in Hook. f. Fl. Brit. Ind. VI. 630, et in Journ. Linn. Soc. XXXVI. 228.

Barbs of the bristles close, style-base about $1 / 2$ as long as the nut. Determination unsatisfactory.

236. Fimbristylis miliacea Vahl.; Kunth, Enum. Pl. II. 230 ; Benth. F1. Hongk. 393 ; Bøeck. in Linnæa XXXVII. 43, et in Engl. Bot. Jahrb. VI. 51; Clarke in Hook. f. Fl. Brit. Ind. VI. 644; Diels in Engl. Bot. Jahrb. XXIX. 229 ; Clarke 
in Journ. Linn. Soc. XXXVI. 239. (Chang, no. 152.)

Nom. Jap. Hideriko.

237. Mariscus Sieberianus Nees in Linnæa IX. 286 ; Clarke in Hook. f. Fl. Brit. Ind. VI. 622, et in Journ. Linn. Soc. XXXVI. 221. (Chang, no. 153.)

Nom. Jap. Kugu.

238. Scrirpus mucronatus L. ; Kunth, Enum P1. II. 161.; Bœck. in Linnæa XXXVI. 703 ; Clarke in Hook. f. Fl. Brit. Ind. VI. 657, et in Journ. Linn. Soc. XXXVI. 252 ; Diels in Engl. Bot. Jahrb. XXIX. 228.

Nom. Jap. Kangarei.

\section{Gramineæ.}

239. Alopecurus æqualis Sobol.; Rendle in Journ. Linn. Soc. XXXVI. 384; $=$ A. geniculatus L. ; Pilger in Engl. Bot. Jahrb. XXIX. 224. (Chang, no. 158.)

Nom. Jap. Suzume-no-teppô.

240. Avena fatua L.; Steud. Syn. Gram. 230 ; Benth., F1. Hongk. 430 ; Hook. f. Fl. Brit. Ind. VII. 275 ; Rendle in Journ. Linn. Soc. XXXVI. 401. (Chang, no. 157.)

Nom. Jap. Chahiki.

241. Imperata arundinacea Cyr. ; Miq. Prol. 196 ; Fr. et Sav. Enum. P1. Jap. II. 188. (Chang, no. 159 a, 150 b).

Nom. Jap. Chigaya. (白茅).

242. Lophatherum sinense Rendle in Journ. Linn. Soc. XXXVI. 421. (Chang, no. 163.)

The present specimen seems to agree well with the description of Rendle. The spikelet has about 10 sterile glumes above the fertile one, but the author does not state anything about the sterile glumes. He saw single specimen which was collecled at Kiu-kiang, Kiang-si; and if my identification is right the species is also found in Che-kiang.

243. Oryza sativa L. ; Steud. Syn. Gram. 3 ; Thunb. F1. Jap., 147 ; Rendle in Journ. Linn. Soc. XXXVI. 344. (Chang, no. 160).

Nom. Jap. Ine. (稻). 
244. Panicum plicatum Lamk.; Trin. Sp. Gram. Ic. t. 223 ; Kunth, Eunm. P1. I. 94 ; Benth., F1. Hongk. 411 ; Hook. f. Fl. Brit. Ind. VII. 55 ; Pilger in Engl. Bot. Jahrb. XXIX. $223 ;=P$. neurodes Schult., Matsum. Index F1. Jap. vol. II. 1, p. 71 ; =Setaria Mauritiana Spreng. ; Rendle in Journ. Linn. Soc. XXXVI. $336 ;=P$. excurrens Trin. Ic. Gram. t. 89.

Nom. Jap. Sasakibi.

245. Phragmitis communis Trin. ; Steud. Syn. Gram. 195 ; Fr. et Sav. Enum. P1. Jap. II. 170 ; Hook. f. F1. Brit. Ind. VII. 303 ; Rendle in Journ. Linn. Soc. XXXVI. 409.

Nom. Jap. Yoshi. (蘆).

246. Rottoboellia compressa L. f. var. japonica Hack. Monogr. Androp. 288 et in Bull. Herb. Boiss. sér. 2., III. 501 ; Rendle in Journ. Linn. Soc. XXXVI. 361.

Nom. Jap. Ushi-no-shippei

247. Saccharum arundinaceum Retz., Hack. Monogr. Androp. 117 ; Rendle in Journ. Linn. Soc. XXXVI. $349 ;=S$. procerum Roxb. Fl. Ind. I. 243. (Chang. no. 162).

248. Spodiopogon cotulifera Hack. Monogr. Androp. 181; et in Bull. Herb. Boiss. VII. (1899) 641 et sér. 2. III. (1903) 501 ; Hook. f. Fl. Brit. Ind. VII. 108 ; Rendle in Journ. Linn. Soc. XXXVI. 351. (Chang, no. 161).

Nom. Jap. Abura-susuki.

\section{Filices.}

249. Asplenium incisum Thunb., Hook. Synop. Fil. 217 ; Diels in Engl. Bot. Jahrb. XXIX. 198.

Nom. Jap. Toranoo-shida.

250. A. Saulii Hook. ; Hook. et Bak. Synop. Fil. 216 ; Diels 1. c.

Nom. Jap. Kobano-hinoki-shida.

251. Davallia Griffithiana HK. ; Benth. Fl. Hongk. 462 ; Matthew in Journ. Linn. Soc. XXXIX. 356.

Nom. Jap. Shima-shinobu.

252. Diplazium japonicum Bedd.; Benth., Fl. Hongk. 452 . 
Nom. Jap. Shike-shida.

253. D. Wichuræ (Wett.) Diels ; Bak. in Journ. Linn. Bot. XIII. (1875) 220 ; Diels 1. c. 197 ; Matthew 1. c. 358. (Chang, no. 76$)$.

Nom. Jap. Nokogiri-shida.

254. Drynaria Fortunei (Kze.) J. Sm. ; Hook. et Bak. Synop. Fil. 367 ; Diels 1. c. 207 ; Matthew 1. c. 359. (Chang, no. 173).

255. Nephrodium decursivo-pinnatum Bak.; Hook. et Bak. Synop. Fil. 259 ; Diels 1. c. 189.

Nom. Jap. Gejigeji-shida.

256. Nephrodium Filix-mas Rich. var. erythrosorum Chr.; Matsum. Index Pl. Jap. I. $319 ;=N$. (Furcatoveniæ) eryphrosorum Hook. ; Diels 1. c. 190. (Chang, no. 175.)

Nom. Jap. Beni-shida.

257. N. oligophlebium Chr.; Matsum. Index Pl. Jap. I. $288 ;=N$. (Dissectæ) setigerum (B1.) Bak. ; Diels 1. c. 191.

Nom. Jap. Himewarabi.

258. N. sophoroides (Thunb.) Desv.; Hook. et Bak., Synop. Fil. 289 ; Diels 1. c. ; (Chang, no. 172 a, 172 b.)

Nom. Jap. Hoshida.

259. Polypodium ellipticum Thunb.; Benth. Fl. Hongk. 457 ; Hook. et Bak. Synop. Fil. 289 ; Diels 1. c. 206 ; Matthew in Journ. Linn. Soc. XXXIX. 378 ;

var. typicum Makino in sched., Herb. Imp. Univ. Tokyo. (Chang, no. 167).

Nom. Jap. Iwahitode.

260. P. nipponicum Mett.; Hook. et Bak., Synop. Fil. 341 ; Diels 1. c. 203 ; Matthew. 1. c. 381.

Nom. Jap. Aone-kadzura.

261. P. normale Don; Diels 1. c. ; 204 Matthew. 1. c. ;

var. normalis Hook. Sp. Fil. V. 70. (Chang, no. 169a, $169 b)$.

262. P. phyllomanes Chr.; Matthew. 1. c. $382 ;=P$. ovatum Wall. ; Hook. et Grev. Ic. t. 41. (Chang, no. 165).

263. P. petiolosum Chr. et Baroni ; Palibin in Conspect. Fl. Cor. III. $42 ;-$ Niphobolus petiolosus Diels in Engl. Bot. 
Jahrb. XXIX. 207 ; Yabe, Filices Koreæ Uchiyamanæ in Bot. Mag. Tokyo XXII (1903)68. (Chang, no. 166.)

264. P. superficiale Bl.; Benth. Fl. Hongk. 458 ; Hook. et Bak. Synop. Fil. 355 ; Diels 1. c. 203 ; Matthew. 1. c. 383. (Chang, no. 168).

Nom. Jap. Nukaboshi-kuriharan, nukaboshiran.

265. Polystichum aculeatum (L.) Schott.; Hook. et Bak. Synop. Fil. 252 ; Diels 1. c. 193 ; Christensen, Index Filicum 575 ; Mathew. 1.c. 384. (Chang, no. 177.)

266. P. falcatum Diels ; Hook. et Bak. 1. c. 257 ; Diels 1. c. 194 ; Matthew. 1. c. 385.

Nom. Jap. Yabu-sotetsu.

267. P. varium (Sw.) Presl.; Hook. et Bak. 1. c. 254; Diels 1. c. 194 ; Matthew 1. c. 388. (Chang, no. 174).

Nom. Jap. Itachi-shida.

268. Pteris semipinnata L.; Benth. Fl. Hongk. 448; Diels 1. c. 202 ; Matthew. 1. c. 390 ;

var. dispar Bak.; Hook. Synop. Filicum 157 ;=var. subaequilateræ Hook. (Chang, no. 164).

Nom. Jap. Amakusa-shida.

269. Woodwardia radicans Sm.; Hook. et Bak. Synop. Fil. 188 ; Diels 1. c. 199 ; Matthew. 1. c. 393.

Nom. Jap. Komochi-shida.

270. W. virginica Sm.; Matsum. Index. P1. Jap. I. 352 ; $=W$. japonica Sw. ; Hook. et Bak. Synop. Fil. 188 ; Diels 1. c. 199 ; Matthew. 1. c. 393. (Chang, no. 170a, 170b).

Christensen (in Index Filicum pp. 658, 659.) retains both $W$. virginica and japonica; but Matsumura and others reduce var. japonica to virginica, and here I follow the latter view. 